TAPROBANICA, ISSN 1800-427X. October, 2010. Vol. 02, No. 02: pp. 105-108.

(C) Taprobanica Nature Conservation Society, 146, Kendalanda, Homagama, Sri Lanka.

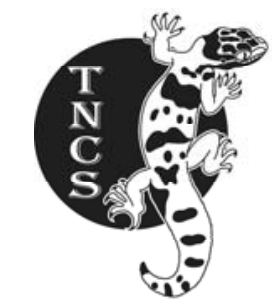

\section{Utilization of food plant species and abundance of hanuman langurs (Semnopithecus entellus) in Pench Tiger Reserve, Madhya Pradesh, India}

Utilization of food plant species and abundance of hanuman langurs (Semnopithecus entellus) were studied between January 2009 and August 2010 in Pench Tiger Reserve, Madhya Pradesh ( $78^{\circ} 55^{\prime}$ to $79^{\circ} 35^{\prime} \mathrm{E}$ and $21^{\circ} 8^{\prime}$ to $22^{\circ} \mathrm{N}$ ), India. This nature reserve is in the southern lower reaches of the Satpura Hill Range, on the southern border of Madhya Pradesh and covers an area of $758 \mathrm{~km}^{2}$. According to Champion \& Seth (1968) Pench Tiger Reserve is under both tropical dry and moist deciduous forest systems. Floristically, Pench is very rich and composed with 189 tree species, 138 shrubs, 452 herbs, 102 climbers, 10 epiphytes and parasites and 119 grasses and bamboos (Dungariyal, 2008). The year is broadly grouped into four major seasons: summer (March to June), monsoon (July to August), post monsoon (September to October) and winter (November to February). Temperature varies annually from $2{ }^{\circ} \mathrm{C}$ in winter to $49^{\circ} \mathrm{C}$ in summer. The average rainfall is almost $1400 \mathrm{~mm}$ (Biswas \& Sankar, 2002). Hanuman langur is listed as the least concern species in IUCN red list categories, CITES Appendix I and Schedule II in Wildlife Protection Act 1972 (India).

We studied the utilization of different food plant species by hanuman langurs opportunistically in the study area. Overall, different plant parts of 50 plant species (Table 1) were utilized by hanuman langurs during the study period.

Distance sampling by line transect method (Burnham et al., 1980; Buckland et al., 1993) was used to estimate approximate densities of hanuman langurs in the intensive study area $\left(410 \mathrm{~km}^{2}\right)$. We walked a total of 44 line transects in both summer and winter (total effort $752.8 \mathrm{~km} /$ season). Each transect was walked early in the morning (Schaller,
1967; Jhala et al., 2008) and radial distance (using a laser range finder) and sighting angles (using a SUNTO compass) were recorded in each detection. DISTANCE version 5.0 was used to analyze the data. The results from line transects showed that densities of adult hanuman langurs were $73.8 / \mathrm{km}^{2}$ ( $\mathrm{SE} \pm 6.4$ ) during winter and $91.2 / \mathrm{km}^{2}(\mathrm{SE} \pm 9.2)$ in summer (Table 2). Densities were multiplied by the study area $\left(410 \mathrm{~km}^{2}\right)$ to obtain populations of hanuman langur in winter 30347 (SE \pm 2637) and in summer 37532 (SE \pm 3790). Average troop size was 7.1 in winter and 8.7 in summer.

On comparison with other studies of Indian subcontinent it is evident that Pench harbours a very high density of hanuman langur (Table 3). A combination of factors is responsible for their high abundance in Pench Tiger Reserve. First they were found to be less preferred by large carnivore species found in the study area as compared to their availability (Biswas \& Sankar, 2002). Second, the study area is dominated by fairly open canopy, mixed forest with considerable shrub cover interspersed with small open grassy patches. The relationship (Newton, 1989) between troop of hanuman langur and axis deer (Axis axis) may be one of the major reasons in such type of habitat for their less predation as the axis deer population is also high in Pench Tiger Reserve (Biswas \& Sankar, 2002). Although, the study area is mostly tropical dry deciduous forest (Champion \& Seth, 1968), not all plant species loose their leaves at the same time. Many plant species are in their deciduous phase in some parts of the study area while others remain in leaf. The langurs debarked some selectively soft-bark species such as Schleichera oleosa, Terminalia arjuna, Mitragyna parvifolia, Terminalia tomentosa, Lanea coromandelica, Boswellia serrata and Anogeissus latifolia. We have opportunistically found that sometimes hanuman langurs sitting on ground were very fond of the dry seeds of the Ougeinia dalbergioides tree. We also found, strangely, that hanuman langurs utilized not whole plants, but some portion such as the leaf apex of Butea monosperma, mid vein of the leaf of Terminalia 
tomentosa, fruit apex of Madhuca longifolia, and fruit apex of Syzygium cumini in summer. We observed langurs taking fresh bark of trees mostly during summer as 'famine food' to overcome food scarcity. Therefore, regular availabilities of resources in the study area and their hardy and highly adaptive nature (Raemakers, 1980; Marsh, 1981; Isbell, 1983; Bennett, 1986; Newton, 1992) may have enabled them to recruit though out the year in Pench.

Table 1: Overall utilization of food plant species by hanuman langurs (Semnopithecus entellus) in Pench Tiger Reserve, between January 2009 and August 2010 (for plant type, T=tree; C= climbers; G=grass; S=shrub and for season, $\mathrm{S}=$ summer; $\mathrm{W}=$ winter)

\begin{tabular}{|c|c|c|c|c|c|}
\hline no & Plant Species & Family & Plant type & Season & Plant parts utilized \\
\hline 1 & Terminalia arjuna & Combretaceae & $\mathrm{T}$ & $\mathrm{S}$ & Young leaves and bark \\
\hline 2 & Syzygium cumini & Myrtaceae & $\mathrm{T}$ & $\mathrm{S}$ & Young leaves and young flower \\
\hline 3 & Bahunia vahlii & Leguminosae & $\mathrm{C}$ & $\mathrm{S}$ & Young flower \\
\hline 4 & Diospyros melanoxylon & Ebenaceae & $\mathrm{T}$ & S \& W & Ripe fruit and young leaves \\
\hline 5 & Buchnania lanjan & Anacardiaceae & $\mathrm{T}$ & $\mathrm{S}$ & Young leaves, ripe and un ripe fruit \\
\hline 6 & Ficus infectoria & Moraceae & $\mathrm{T}$ & S \& W & Young leaves \\
\hline 7 & Schleichera oleosa & Sapindaceae & $\mathrm{T}$ & S \& W & Young leaves, ripe fruit and bark \\
\hline 8 & Lanea coromandelica & Anacardiaceae & $\mathrm{T}$ & S \& W & Young leaves, ripe fruit and latex \\
\hline 9 & Ficus bengalensis & Moraceae & $\mathrm{T}$ & $\mathrm{S}$ & Young leaves and ripe fruit \\
\hline 10 & Ougeinia dalbergioides & Leguminosae & $\mathrm{T}$ & $\mathrm{S}$ & Young leaves, flower, latex and dry seed \\
\hline 11 & Lantana camara & Verbenaceae & $\mathrm{S}$ & S \& W & Young leaves and young flower \\
\hline 12 & Soymida febrifuga & Meliaceae & $\mathrm{T}$ & $\mathrm{S}$ & Young leaves \\
\hline 13 & Albizzia procera & Leguminosae & $\mathrm{T}$ & $\mathrm{S}$ & Bark \\
\hline 14 & Madhuca longifolia & Sapotaceae & $\mathrm{T}$ & S \& W & $\begin{array}{l}\text { Flower, young leaves, apex of un ripe fruit } \\
\text { and bark }\end{array}$ \\
\hline 15 & Butea monosperma & Leguminosae & $\mathrm{T}$ & S \& W & Flower and young leaves \\
\hline 16 & Mangefera indica & Anacardiaceae & $\mathrm{T}$ & $\mathrm{S}$ & Young leaves, flower and ripe fruit \\
\hline 17 & Semecarpus anacardium & Anacardiaceae & $\mathrm{T}$ & $\mathrm{S}$ & Ripe fruit \\
\hline 18 & Ficus glomerata & Moraceae & $\mathrm{T}$ & S \& W & Young leaves \\
\hline 19 & Lagerstroemia purviflora & Lythraceae & $\mathrm{T}$ & S \& W & Young leaves \\
\hline 20 & Acacia catechu & Leguminosae & $\mathrm{T}$ & $\mathrm{W}$ & Young leaves \\
\hline 21 & Cynodon dactylon & Poaceae & $\mathrm{G}$ & $\mathrm{W}$ & Node and inter node, young leaves \\
\hline 22 & Tamarindus indica & Leguminosae & $\mathrm{T}$ & $\mathrm{S}$ & Young leaves \\
\hline 23 & Miliusa velutina & Annonaceae & $\mathrm{T}$ & $\mathrm{S}$ & Fruit, young leaves \\
\hline 24 & Zizyphus mauritiana & Rhamnaceae & $\mathrm{T}$ & $\mathrm{S}$ & Ripe fruit \\
\hline 25 & Dalbergia paniculata & Leguminosae & $\mathrm{T}$ & $\mathrm{S}$ & Young leaves \\
\hline 26 & Mitragyna parvifolia & Rubiaceae & $\mathrm{T}$ & S \& W & Young leaves and bark \\
\hline 27 & Bombax ceiba & Bombacaceae & $\mathrm{T}$ & S \& W & Flower \\
\hline 28 & Ficus religiosa & Moraceae & $\mathrm{T}$ & $\mathrm{S}$ & Young leaves \\
\hline 29 & Aegle marmelos & Rutaceae & $\mathrm{T}$ & $\mathrm{S}$ & Ripe fruit \\
\hline 30 & Zizyphus xylopyra & Rhmanaceae & $\mathrm{T}$ & $\mathrm{W}$ & Young leaves and ripe fruit \\
\hline 31 & Bauhinia racemosa & Leguminosae & $\mathrm{T}$ & $\mathrm{W}$ & Young leaves \\
\hline 32 & Cleistanthus collinus & Phyllanthaceae & $\mathrm{T}$ & S \& W & Young leaves \\
\hline 33 & Terminalia tomentosa & Combretaceae & $\mathrm{T}$ & S \& W & Young leaves \\
\hline 34 & Cordia myxa & Boraginaceae & $\mathrm{T}$ & $\mathrm{S}$ & Ripe fruit \\
\hline 35 & Stereospermum chelonoides & Bignoniaceae & $\mathrm{T}$ & $\mathrm{S}$ & Young leaves \\
\hline 36 & Casia fistula & Leguminosae & $\mathrm{T}$ & S \& W & Flower and ripe fruit \\
\hline 37 & Gardenia latifolia & Rubiaceae & $\mathrm{T}$ & $\mathrm{S}$ & Flower, fruit and mature leaves \\
\hline 38 & Ixora parviflora & Rubiaceae & $\mathrm{T}$ & $\mathrm{W}$ & Young leaves \\
\hline 39 & Heteropogon contortus & Poaceae & $\mathrm{G}$ & S \& W & Node and inter node \\
\hline 40 & Anogeissus latifolia & Combretaceae & $\mathrm{T}$ & S \& W & Young leaves and bark \\
\hline 41 & Chloroxylon swietenia & Rutaceae & $\mathrm{T}$ & $\mathrm{W}$ & Young leaves \\
\hline 42 & Pterocarpus marsupium & Leguminosae & $\mathrm{T}$ & S \& W & Young leaves \\
\hline 43 & Alangium lamarckii & Alangiaceae & $\mathrm{T}$ & $\mathrm{S}$ & Bark \\
\hline 44 & Boswellia serrata & Burseraceae & $\mathrm{T}$ & S \& W & Young leaves \\
\hline 45 & Sterculia urens & Sterculiaceae & $\mathrm{T}$ & $\mathrm{S}$ & Latex \\
\hline 46 & Adina cordifolia & Rubiaceae & $\mathrm{T}$ & S \& W & Young leaves and ripe fruit \\
\hline 47 & Datura metel & Solanaceae & $\mathrm{S}$ & $\mathrm{S}$ & Young leaves \\
\hline
\end{tabular}




\begin{tabular}{|l|l|l|c|c|l|}
\hline 48 & Chloris virgata & Poaceae & G & W & Node and inter node \\
\hline 49 & Hardwickia binnata & Leguminosae & T & S \& W & Young leaves and bark \\
\hline 50 & Emblica officinalis & Euphorbiaceae & T & S \& W & Young leaves, ripe and unripe fruit \\
\hline
\end{tabular}

Table 2: Seasonal variation of densities, populations and troop sizes of hanuman langurs (Semnopithecus entellus) in Pench Tiger Reserve, Madhya Pradesh (January 2009 and August 2010)

\begin{tabular}{|l|c|c|c|c|c|c|c|c|}
\hline \multirow{2}{*}{ Seasons } & \multirow{2}{*}{ Observations } & \multirow{2}{*}{$\mathrm{D} \pm \mathrm{SE}$} & \multirow{2}{*}{ Population $\pm \mathrm{SE}$} & \multicolumn{5}{|c|}{ Troop size \% } \\
\cline { 5 - 9 } & & & & $1-10$ & $11-20$ & $21-30$ & $31-40$ & $41-50$ \\
\hline Winter & 610 & $73.8 \pm 6.4$ & $30347 \pm 2637$ & 78.2 & 18.6 & 3 & 0.2 & 0 \\
\hline Summer & 795 & $91.2 \pm 9.2$ & $37532 \pm 3790$ & 69.6 & 23.8 & 4.9 & 1.3 & 0.5 \\
\hline
\end{tabular}

D: Individual density, SE: Standard Error

Table 3: Densities of hanuman langurs compared with different study areas in the Indian sub-continent.

\begin{tabular}{|c|c|c|}
\hline Location & Forest type & Density $/ \mathbf{k m}^{2}$ \\
\hline Bandipur $^{1}$ & Tropical dry deciduous & 7.5 \\
\hline Pench $^{2}$ & Tropical dry and moist deciduous & 77.2 \\
\hline Bhadra $^{3}$ & Tropical moist deciduous & 22.6 \\
\hline Ranthambore $^{4}$ & Tropical thorn and dry deciduous & 21.7 \\
\hline Bori-Satpura $^{5}$ & Tropical dry and moist deciduous & 28.3 \\
\hline Mudumalai $^{6}$ & $\begin{array}{l}\text { Tropical dry thorn, moist, dry } \\
\text { deciduous and semi evergreen }\end{array}$ & 25.9 \\
\hline Present study* & Tropical dry and moist deciduous & 82.5 \\
\hline
\end{tabular}

\section{Acknowledgments}

We are extremely grateful to Madhya Pradesh Forest Department for granting permission for the research work “Ecology of Tiger” project. We also thank National Tiger Conservation Authority, India, Director and Dean, Wildlife Institute of India. Kuladeep Roy of Mysore University, Dr. Pankaj Sahane of WII and our field assistants Gurhanlal and Brijlal are also acknowledged for their support.

\section{Literature Cited}

Bagchi, S., S. P. Goyal, and K. Sankar, 2003. Prey abundance and prey selection by tigers (Panthera tigris) in a semi arid, dry deciduous forest in western India. Journal of Zoology, 260: 285-290.

Bennett, E. L., 1986. Environmental correlates of ranging behaviour in the banded langur (Presbytis entellus). Folia Primatologica, 47: 26-38.
Biswas, S. and K. Sankar, 2002. Prey abundance and food habit of tigers (Panthera tigris tigris) in Pench National Park, Madhya Pradesh, India. Journal of Zoology, 256: 411-422.

Buckland, S. T., D. R. Anderson, K. P. Burnham and J. L. Laake, 1993. Distance Sampling; Estimating Abundance of Biological Populations. New York, Chapman and Hall: 446.

Burnham, K. P., D. R. Anderson and J. L. Laake, 1980. Estimation of density from line transect sampling of biological populations. Wildlife Monograph, 72: 1-202.

Champion, H. G. and S. K. Seth, 1968. A revised survey of the forest types of India. Manager of Publications, Govt.of India Press, New Delhi: 404. 
Dungariyal, N. S., 2008. Management Plan of Pench Tiger Reserve, Madhya Pradesh. Govt. of Madhya Pradesh Press: 233.

Edgaonkar, E., 2008. Ecology of The Leopard Panthera pardus in Bori Widllife Sanctuary and Satpura National Park, India. Phd Thesis. University of Florida: 135.

Isbell, L. A., 1983. Daily ranging behaviour of red colobus (Colobus badius tephrosceles) in Kibale forest, Uganda. Folia Primatologica., 41: 34-48.

Jathanna, D., 2001. Density, Biomass and Habitat Occupancy of Ungulates in Bhadra Tiger Reserve, Karnataka. Masters Dissertation. Saurashtra University, Rajkot. India: 71.

Jhala, Y. V., R. Gopal and Q. Qureshi, 2008. Status of tigers, co-predators and prey in India. National Tiger Conservation Authority, Govt. of India, New Delhi and Wildlife Institute of India, Dehra Dun, TR 08/001: 164.

Johnsingh, A.J.T., 1983. Large mammalian preypredator in Bandipur. Journal of Bombay Natural History Society, 80: 1-57.
Marsh, C., 1981. Diet choice among red colobus (Colobus badius rufomitratus) on the Tana River, Kenya. Folia Primatologica, 35: 147-178.

Newton, P. N., 1989. Associations between langur monkeys (Presbytis entellus) and chital deer (Axis axis): Chance encounters or a Mutualism? Ethology, 83 (2): 89-120.

Newton P. N., 1992. Feeding and ranging patterns of forest Hanuman langurs (Presbytis entellus). Interanational Journal of Primatology, 13: 245-282.

Raemakers, J. J., 1980. Causes of variation between months in the distance travelled daily by gibbons. Folia Primatologica, 34: 46-60.

Ramesh, T., V. Snehalatha, K. Sankar and Q. Qureshi, 2009. Food habits and prey selection of tiger and leopard in Mudumalai Tiger Reserve, Tamil Nadu, India. Journal of Scientific Transactions of Environment and Technovation, 2: 170-181.

Schaller, G. B., 1967. The deer and the tiger. University of Chicago Press, Chicago: 370.

Submitted: 06 March 2011, Accepted: 22 April 2011 Sectional Editor: Lee Harding

Aniruddha Majumder ${ }^{1,2}$, Abinash Parida ${ }^{1}, \mathrm{~K}$. Sankar ${ }^{1}$ and Qamar Qureshi ${ }^{1}$ ${ }^{1}$ Wildlife Institute of India, P.O, Box 18, DehraDun, 248001,Uttarakhand, India

22Email: aniruddha@wii.gov.in 